\title{
Attitudes to Tipping
}

\author{
Adrian Furnham \\ Norwegian Business School (BI), Olso, Norway \\ Email: a.furnham@ucl.ac.uk
}

How to cite this paper: Furnham, A. (2021). Attitudes to Tipping. Psychology, 12, 805-816.

https://doi.org/10.4236/psych.2021.125049

Received: April 17, 2021

Accepted: May 28, 2021

Published: May 31, 2021

Copyright $\odot 2021$ by author(s) and Scientific Research Publishing Inc. This work is licensed under the Creative Commons Attribution International License (CC BY 4.0).

http://creativecommons.org/licenses/by/4.0/

\begin{abstract}
There is a small, but growing, literature across various disciplines on tipping. In this study, 260 people completed four new, short questionnaires about tipping. The first part looked at personal attitudes to, and behaviours concerning, tipping, and showed that people believe they tip much like others but that the whole process can cause embarrassment. In the second part, they rated eleven statements about tipping, while in the next two parts they reported their frequency of tipping seven groups of workers (e.g., hairdressers, taxidrivers) and how much they gave. As predicted, they said they tipped most frequently to waiters and least to hotel doormen. They claimed to tip around $15 \%-20 \%$ of the bill. Education and age, both linked to income, were most related to tipping beliefs and behaviours. Implications and limitations are discussed.
\end{abstract}

\section{Keywords}

Tipping, Gratuities, Economics, Psychology

\section{Introduction}

The term TIP supposedly stands for "To Insure Promptness": it was derived from the eighteenth century English tradition of giving coins with written words to publicans (Furnham, 2014). It is now a "standard procedure" in many countries to tip waiters/waitresses, porters, hairdressers, taxi-drivers, chambermaids and a host of other "professionals". The question of who to tip, how much and why, however, depends on local, national and cultural norms as well as personal preferences. This study is about peoples' attitudes to tipping which is a topic of controversy, debate and embarrassment. There are few studies on this topic and no instruments designed to measure these attitudes. This modest study hopefully fills a gap in the literature.

Tipping has attracted the attention of economists (Azar, 2005, 2020), psy- 
chologists (Furnham, 2014; Guéguen, 2002), and particularly those in the hospitality and tourism business (Aydin \& Acun, 2019; Gössling et al., 2020; Harris, 1995; Karabas \& Joireman, 2020; Karabas et al., 2020; Harris, 1995; Lynn, 2008, 2018, 2021; Whaley et al., 2014, 2019a, 2019b). It is related to growing multidisciplinary literature on the psychology of money (Furnham, 1984, 1996, 2014; Furnham \& Grover, 2020, 2021; Furnham \& Murphy, 2019; Furnham \& Horne, 2021; Furnham et al., 2012, 2014a, 2014b).

Tipping is a highly controversial topic for individuals as well as businesses. Some want to eradicate the process overall, which they see as inappropriate and corrupt and primarily a function of certain employers not paying a living wage to their employees. Others want to replace individual tipping with a compulsory service charge added to every invoice/bill given by a service provider. Still, others argue that they like to have the opportunity to reward serving staff for their effort and attitude (Furnham, 2014).

Lynn (2015a) noted five motivations for tipping: to 1) help the server, 2) repay/reward the server for his/her efforts, 3) gain/keep good service in future encounters with the server, 4) gain/keep the server's and other observers' esteem and 5) fulfill a social obligation or duty. These motives are likely to mediate the effects of most situational, individual, occupational and national determinants of tipping behaviour.

Researchers in this area have asked a number of specific questions: What is the meaning and function of tipping? Why does it exist? What are the determinants of tipping? How does tipping affect the service-givers (e.g., waiters), the recipients (i.e., customers) and the relationship between the two parties? People from different disciplines have theorised about the issue very differently (Shamir, 1983, 1984). There are however, relatively few studies that have asked people their attitudes, beliefs and habits concerning the whole issue of tipping.

Psychologists suggest that tipping is a form of ego massage calculated to enhance the self-image of the tipper. Also, by giving a tip-above and beyond the agreed set price-the tipper can demonstrate he/she is not fully trapped by market forces and can be capable of voluntary, discretionary action. The tip can also sometimes be seen as a result of the customer's insecurity or anxiety. A maid or hairdresser deserves a tip through having access to the customer's private territory or articles that may pose a threat to the customer's public face. The tip can buy their server's silence because it buys loyalty or indebtedness. Psychologists stress that tipping is intrinsically motivated rather than performed for the sake of the external material or social rewards (Furnham, 2014).

Lynn and Grassman (1990) suggested three "rational" explanations for tipping. First, buying social approval with tips: following the social norms (i.e., 15\% tipping) is a desire for social approval, or else a fear of disapproval. Second, buying an equitable relationship with tips: tips buy peace-of-mind by helping maintain a more equitable relationship with the servers/providers of a service. Third, buying future service with tips: tips ensure better service in the future because the 
tit-for-tat works, but only with regular customers. In their study they found support for the first two, but not the third, explanation.

Lynn and Latane (1984) summarised the results from early studies: most tips are around the 15\% American norm; the percentage of the tip to total cost is an inverse power function of the number of people at the table; physically attractive and/or attractively dressed waitresses receive greater tips than less attractive waitresses; tips are bigger when paid by credit cards, relative to cash payers; tips are not related to whether alcohol is consumed; tips increase with the number of non-task oriented "visits" by waiter and waitress, but are unrelated to the customers ratings of service; often, but not always, males tip more than females.

Some studies have focused on the server's behaviour. Rind and Bordia (1995) noted that server (waiter/waitress/waitron)-diner interactions were related to tip size. Variables that have been investigated include: whether the server touched the diner; whether the server initially squatted in their interaction with the diner as opposed to stood; the size (and guineness) of their initial (greeting) smile; whether the server introduced him/herself with their first name; and the number of incidental (non-task oriented) visits to the table. Others which have been suggested or examined include: whether waitrons wear make-up and a flower in their hair and draw smiley faces on receipts; whether waitrons to draw the sun on receipts; the use of hand-written messages on the receipts, like "thank you" or a weather forecast; waitrons address customers by name and introduce themselves; staff mimic customers' body language and verbal behaviour, and touch them appropriately during interactions.

One tool for effective tipping is the "liking" heuristic. Tips can be significantly increased by anywhere up to $140 \%$ by: wearing a fllowers in their hair or wearing make-up; repeating the customers' orders after they have said them; addressing customers by name (e.g. "Mr. Smith"); servers introducing themselves by name; using large, open-mouthed smiles, as opposed to small, closed ones; subtly touching customers on the shoulder and hand during interactions; mimicking verbal behaviour and posture; by squatting to the customer's level.

The second useful heuristic for encouraging tipping is "reciprocity"-people tend to help those who have helped them before. This does not have to be costly though. Tips are significantly increased by giving customers a puzzle, joke or interesting fact with the receipt; giving customers a hand written message forecasting the weather or saying "thank you"; drawing a smiley face on the receipt, though they can get the same result by drawing the sun; giving customers a sweet, though giving them two is better and giving them two at different times is even more effective than that (Guéguen, 2002; Rind \& Bordia, 1995; Strohmetz et al., 2002).

In all his many studies on tipping, Lynn suggests that tipping for all sorts of service in many different countries is primarily driven by three things: the desire to reward good quality service, to help the service providers, and to personally gain social approval and status. More recently he has noted two other factors: 
gaining good quality service in the future as well as conform to internalised tipping norms (or doing what is right). He and colleagues have studied many different groups including car guards in South Africa (Saunders \& Lynn, 2010) as well as waiters in America (Lynn et al., 2012).

These studies have looked at all sorts of factors that might have a small influence on the tipping behaviour of individuals. These include the sex and race of the server and the sex, race, age, education, income, worship frequency and alcohol consumption of the customer. Inevitably Lynn does find that the bigger the bill, the bigger the tip.

Comparatively few studies have looked at attitudes to tipping. Lynn (2015b) devised a 37-item scale with six factors. These referred to future-service motives (to get better service in the future), a reward (saying thank you for efforts), avoidance of feeling disliked or indebted, duty to obey customs and norms, altruism to help others and self-esteem (appearing generous). Results indicate that motives for tipping predicted the likelihood of tipping, and the tip sizes. The effects of future service and duty motives varied across service occupations; duty motives had opposite effects on the likelihood of tipping and on the size of tip; reward, altruistic and esteem motives were positively related to attitudes toward tipping; avoidance and duty motives were negatively related to attitudes toward tipping.

This study looked primarily at attitudes to tipping. It has three parts. The first part looked at personal beliefs and habits concerning tipping. The second part concerned general attitudes to tipping based on the previous literature. The aim was to get some indication of attitudes in an international sample. The third part concerned how much people said they would tip specific individuals.

\section{Method}

\subsection{Participants}

In all there were 260 primarily American participants, of which 119 were male and 141 female. They ranged in age from 19 to 70 years old ( $M=36.38 \mathrm{yrs} ; S D=$ 10.59). In all 213 (82\%) identified themselves as White, 18 (7\%) Black, 15 (6\%) Asian and 10 (4\%) Hispanic. Just under 30\% had a completed high school education, $8 \%$ were in full-time education and the remainder a university degree. In all $55 \%$ had taken a course in social science/psychology or psychiatry. Asked to rate themselves on "How religious are you?" (from $1=$ "Not at all" to $8=$ "Very much") the mean was $3.42(S D=2.52)$; "Compared to other people, how much common sense do you believe you have?" (from $1=$ "Not at all" to $8=$ "Very much") the mean was 6.45 ( $S D=1.97)$; and "How would you describe your political orientation?" (from $1=$ "Strongly Liberal" to $8=$ "Strongly Conservative") the mean was $3.99(S D=1.98)$.

\subsection{Questionnaire}

A three-part questionnaire was design for this study. 
1) The first part involved 15 questions that had YES/NO answers (see Table $1)$.

2) The second part had eleven attitudinal statements each responded to on a 7-point $(1=$ Disagree, $7=$ Agree $)$ response scale (see Table 2$)$.

3) The third part asked people how much money they would give to seven serving people given the cost of the transaction (see Table 3).

Each part of the questionnaire was based on a review of the literature, as well as personal experience and interviews with six people on the topic. The questionnaires were piloted for their clarity. Participants were also asked to answer various personal questions which provided the information for the participants section of the study.

Table 1. Items about tipping.

\begin{tabular}{|c|c|c|c|}
\hline Number & Item & Yes & No \\
\hline 1 & Do you believe you tip pretty much like other people? & $83.5 \%$ & $16.5 \%$ \\
\hline 2 & Do you think that all tips are legally subject to income tax? & $61.2 \%$ & $38.8 \%$ \\
\hline 3 & $\begin{array}{l}\text { Would you tolerate higher prices in restaurants in order to } \\
\text { do away with tips? }\end{array}$ & $49.2 \%$ & $50.8 \%$ \\
\hline 4 & $\begin{array}{l}\text { Do you believe it is wrong to underpay staff and make them } \\
\text { rely on tips? }\end{array}$ & $79.6 \%$ & $20.4 \%$ \\
\hline 5 & $\begin{array}{l}\text { Do you feel pressured to tip even when you feel you have } \\
\text { received some bad service? }\end{array}$ & $64.6 \%$ & $35.4 \%$ \\
\hline 6 & $\begin{array}{l}\text { Do you tend to reward proportionately to the service that } \\
\text { you receive? }\end{array}$ & $79.2 \%$ & $20.8 \%$ \\
\hline 7 & $\begin{array}{l}\text { Do you prefer "free of discretionary tipping" over a set } \\
10 \%-15 \% \text { service charge? }\end{array}$ & $63.1 \%$ & $36.9 \%$ \\
\hline 8 & $\begin{array}{l}\text { Do you feel waiters and others expect a tip even when a } \\
\text { restaurant have a set service charge? }\end{array}$ & $74.6 \%$ & $25.4 \%$ \\
\hline 9 & $\begin{array}{l}\text { Have you ever tipped some-one before receiving a } \\
\text { service to try to ensure better service? }\end{array}$ & $25.0 \%$ & $75.0 \%$ \\
\hline 10 & $\begin{array}{l}\text { Have you ever do holiday tipping to holiday hotel staff, } \\
\text { Xmas tipping to babysitters, post people, refuse collectors? }\end{array}$ & $46.5 \%$ & $53.5 \%$ \\
\hline 11 & Do you ever gift tip (flowers, chocolates) instead of money? & $13.8 \%$ & $86.2 \%$ \\
\hline 12 & $\begin{array}{l}\text { Have you ever refused to pay the service charge } \\
\text { because of bad service? }\end{array}$ & $24.2 \%$ & $75.8 \%$ \\
\hline 13 & Do you tip more at places you visit more often? & $64.2 \%$ & $35.8 \%$ \\
\hline 14 & $\begin{array}{l}\text { Do you feel guilt or embarrassed if you forget to } \\
\text { tip someone? }\end{array}$ & $80.4 \%$ & $19.6 \%$ \\
\hline 15 & $\begin{array}{l}\text { Do you think you tip more when you pay by credit card as } \\
\text { opposed to cash? }\end{array}$ & $35.0 \%$ & $65.0 \%$ \\
\hline
\end{tabular}


Table 2. Principal component analysis of tipping items with varimax rotation.

\begin{tabular}{|c|c|c|c|c|c|c|}
\hline & M & SD & 1 & 2 & 3 & 4 \\
\hline Urbanites tip more than rural people & 4.38 & 1.49 & .442 & -.144 & .247 & .304 \\
\hline $\begin{array}{l}\text { Most people would rather have the } \\
\text { service charge added to the bill }\end{array}$ & 3.94 & 1.62 & .153 & -.157 & .709 & -.013 \\
\hline $\begin{array}{l}\text { Tipping staff only encourages } \\
\text { employers }\end{array}$ & 3.98 & 1.54 & -.019 & .081 & .808 & .049 \\
\hline $\begin{array}{l}\text { Men often show off by generous } \\
\text { tipping }\end{array}$ & 4.65 & 1.39 & .563 & .094 & .302 & .196 \\
\hline $\begin{array}{l}\text { Some workers get revenge on } \\
\text { customers who don't tip }\end{array}$ & 4.83 & 1.34 & .683 & .234 & .032 & -.131 \\
\hline $\begin{array}{l}\text { I think tipping is an excellent system } \\
\text { to promote better service }\end{array}$ & 3.86 & 1.60 & -.070 & .363 & -.446 & .574 \\
\hline $\begin{array}{l}\text { Tips often reflect the physical } \\
\text { attractiveness of the service staff } \\
\text { more than their quality of service }\end{array}$ & 3.89 & 1.60 & .615 & -.515 & .073 & .132 \\
\hline $\begin{array}{l}\text { The vast majority of people do not } \\
\text { report their tips to the taxman }\end{array}$ & 5.07 & 1.38 & .615 & .268 & -.138 & -.095 \\
\hline $\begin{array}{l}\text { Tips should reflect exactly the quality } \\
\text { of service that you received }\end{array}$ & 5.42 & 1.31 & .179 & .787 & .080 & -.126 \\
\hline $\begin{array}{l}\text { Workers prefer personal tips to a } \\
\text { service charge }\end{array}$ & 4.97 & 1.34 & .206 & .672 & -.211 & .263 \\
\hline $\begin{array}{l}\text { Tipping in advance of service is good } \\
\text { for both parties concerned }\end{array}$ & 3.27 & 1.51 & .025 & -.063 & .102 & .831 \\
\hline
\end{tabular}

Table 3. Frequency of tip in \%.

\begin{tabular}{|c|c|c|c|c|c|}
\hline & Never & Sometimes & $\begin{array}{l}\text { About } \\
\text { half the } \\
\text { time }\end{array}$ & $\begin{array}{l}\text { Most of } \\
\text { the time }\end{array}$ & Always \\
\hline 1) Barbers/Hairdressers & $11.9 \%$ & $10.4 \%$ & $4.6 \%$ & $13.5 \%$ & $59.6 \%$ \\
\hline 2) Coach Drivers & $34.4 \%$ & $14.6 \%$ & $8.5 \%$ & $15.0 \%$ & $27.7 \%$ \\
\hline $\begin{array}{l}\text { 3) Taxi Drivers to } \\
\text { underpay staff }\end{array}$ & $20.8 \%$ & $14.2 \%$ & $8.1 \%$ & $14.6 \%$ & $42.3 \%$ \\
\hline 4) Tour Guides & $39.6 \%$ & $19.6 \%$ & $11.5 \%$ & $12.7 \%$ & $16.5 \%$ \\
\hline 5) Waiters & $2.3 \%$ & $3.1 \%$ & $1.9 \%$ & $15.4 \%$ & $77.3 \%$ \\
\hline 6) Hotel Doormen & $34.6 \%$ & $18.8 \%$ & $9.6 \%$ & $16.5 \%$ & $20.4 \%$ \\
\hline $\begin{array}{l}\text { 7) Hotel Bellboy/Luggage } \\
\text { Porters }\end{array}$ & $16.9 \%$ & $14.6 \%$ & $10.4 \%$ & $21.2 \%$ & $36.9 \%$ \\
\hline
\end{tabular}

\subsection{Procedure}

All data collection was conducted through Amazon Mechanical Turk (MTurk), which has been shown to be demographically diverse and of high quality compared to other online and offline data collection methods for social science research. After giving informed consent, the participants were given information regarding the study and completed a battery of questionnaires. Most participants 
were from North America. Ethical committee permission was sought and received (CEHP/514.2017).

\section{Results}

\subsection{Part 1}

Table 1 shows the results from the first part of the questionnaire. There were five questions where over three quarters of the participants agreed (i.e., ticked YES), including "Do you believe you tip pretty much like other people?" and "Do you feel guilt or embarrassed if you forget to tip someone?". Similarly, in three questions over three quarters disagreed (i.e., ticked NO), including "Do you ever gift tip instead of money?".

Following this, a number of Chi-Square analyses was done for each of the questions. Five of the 15 items showed a sex difference: item 4 (Chi-Square $=$ 9.06, $p<.01)$, item 5 (Chi-Square $=5.35, p<.01)$, item 8 (Chi-Square $=3.77$, $p<.05)$, and item 14 (Chi-Square $=11.13, p<.001)$. Females gave a more "YES" response than males, while males gave a more "YES" responses on item 9 (ChiSquare $=7.07, p<.01$ ).

The sample was split at the median of 35 yrs for age into "young" vs "old" groups and the analyses were repeated. Four items were significant: item 3 (ChiSquare $=4.01, p<.05)$, item $6($ Chi-Square $=8.18, \mathrm{p}<.01)$ and item $12(\mathrm{Chi}-$ Square $=7.69, p<.01)$. Younger people were more likely to say "YES" to item (4), while older people were likely to say "YES" to item 10 (Chi-Square $=4.20, p$ $<.01)$.

The sample was split at the median for religion, political views, but fewer than chance items were significant. Similarly, whether participants had children or not was not systematically related to these attitudes.

\subsection{Part 2}

Table 2 shows the results for the eleven questions. Participants agreed most with the statements "The vast majority of people do not report their tips to the taxman" and "Tips should reflect exactly the quality of service that you received", while they disagreed most with "Tipping in advance of service is good for both parties concerned" and "Tipping is an excellent system to promote better service".

These eleven questions were subjected to an obliquely rotated factor analysis. The first factor (Eigenvalue 2.10, Variance 19.06\%) had five items loading onto it; 4 (.65), 7 (.58), 2 (.54), 5 (.54) and 1 (.53), which reflected a cynical and negative attitude to tipping. The second factor (Eigenvalue 1.99, Variance 18.13\%) had 2 items loading on it, 9 (.78) and 10 (.67), which reflected a worker's perspective. The third factor (Eigenvalue 1.25, Variance 11.34\%) had two items lading on it, 3 (.81) and $2(.71)$, and reflected a negative attitude to tipping. The fourth factor (Eigenvalue 1.01, Variance 9.22\%) had two items loading on it, 11 $(.83)$ and $6(.57)$, and reflected a positive attitude to the tipping progress. 
Table 4. Descriptive statistics of participant's tipping behaviour.

\begin{tabular}{ccc}
\hline Number & Item & Mean (Std. Deviation) \\
\hline 1 & A visit to the hairdresser costing \$40 & $\$ 6.73(4.45)$ \\
2 & A taxi ride costing \$20 Tip & $\$ 5.20(3.07)$ \\
3 & A meal for two costing \$50 Tip & $\$ 9.00(3.63)$ \\
\hline
\end{tabular}

With factor scores as the criterion variable, and the participants' sex, age, religious and political beliefs as well their evaluation of their common sense as the predictor variables, four regressions were calculated. This was only significant for the second factor $\left(\mathrm{F}(5,254)=4.46, p<.001, \mathrm{AdjR}_{2}=.06\right)$. The only significant predictor was common sense $(t=3.85, p<.001)$, which indicated that the more people believed they had common sense, the more they thought workers wanted a tipping system.

\subsection{Part 3}

Table 3 shows the results of the questionnaire that asked participants how often they tipped seven types of workers. Over three quarters claimed to always tip waitrons and over half, hairdressers. Around a fifth claimed to tip tour guides and hotel doormen. A total score was computed which reflected how often they tipped all seven service providers. This was correlated with all six demographic variables. There was no relationship with gender, religiousness or experience of psychology. However, they showed that older people $(r=.26, p<.01)$, those without children $(r=-.14, p<.05)$ and more politically conservative people $(r=.14, p<.05)$ tipped more frequently.

Table 4 shows how much, on average, participants claimed they would give three service providers. They ranged from around a quarter (taxi) to a sixth (hairdresser) of the bill. A total score was computed representing the amount of money they would give to these three service providers. This was not significantly correlated with any other individual difference variables.

\section{Discussion}

Tipping is far from trivial from an economic and social perspective. However, in many countries, it remains a topic and practice of confusion and embarrassment: who to tip, how much, when and why. This modest study looked beliefs and practices in a predominantly North American sample. It demonstrated high degrees of consensus in that there were few individual difference correlates of attitudes and behaviours. However, it may be that there are important individual difference determinants of tipping behaviour, such as trait Agreeableness and Altruism which were not explored in this study and which merit further work.

The results of the first part of the study show that for three questions, over three quarters of the participants agreed with the statements. First, they endorsed the now widely held view that often those they tipped were underpaid and that makes them reliant on tips. Anecdotally that is what waiting staff also say, 
though it is not clear whether they want the tipping system abolished. Many in the serving busy say that tipping is unreliable, uncontrollable and unpredictable and that they would prefer a higher wage and not be reliant on tips.

Nearly $80 \%$ stated that the size of the tip was directly proportionate to service they received, though it is not clear which aspect was most important: courtesy, speed, accuracy, etc. The problem for staff is that while some of these features are in their control, like accuracy and courtesy, speed of delivery is a function of many other factors beyond their control. However, the highest rated statement related to embarrassment about not tipping, for whatever reason. It is clear that they feel it is an expectation which should be honoured. Further, it has been reported that, understanding this, some staff embarrass or humiliate publicly those who refuse to or under-tip. Embarrassment occurs particularly when people move from region to region or country to country where the tipping norms differ.

The second part of the questionnaire reinforced the first. Thus, the item that attracted most agreement was the idea that tips should be directly and strictly proportionate to subjectively determined service quality. The item that attracted second highest agreement was of some interest: participants tended to agree that tips were not declared as income for tax purposes. That is, staff and their employees turned a "blind eye" to the tax avoidance associated with tipping. In many countries, cash tips given to an employee will need to be declared as income to the tax authorities. However, if an employer passes tips to employees that are either handed to him/her (or the employees), or left in a common box/plate, the employer must pay they tax. It seems many people suspect that this does not happen, which means they know they are wilfully but unhappily taking part in a "tax-dodging scam".

The third part of the survey also yielded some very interesting results. Again, the results underlined the important principle of equity, namely the relationship between the quality/quality of the service and the tip. Thus, hotel doormen and coach-drivers received the lowest percentage for two reasons: the size of the bill and their part in the whole "service experience". Certainly, it seems anecdotally that an individual service provider can have a major effect on the whole service experience often by extreme acts of kindness and helpfulness or equally, rudeness and inattentiveness.

Many studies have tried to identify the most important and powerful individual determinants of tipping, be they culture, personality or demography. Recently, Lynn (2021) investigated personality correlates of tipping and concluded that there is little to be gained from using customer's personalities to predict their tipping behaviour.

There are both social and economic implications of studies such as this. For those hoping to change social attitudes and conventions with regard to tipping it is important to understand what people feel about the issue. Further, if tipping behaviour changes by law it will no doubt have implications, and possibly unintended consequences, for those who regularly receive tips and their employers. It 
would be interesting to contrast the behaviour of both serving people and their customers/clients in comparable jobs in different countries where they have very different conventions to explore the many effects of tipping service staff.

Like all studies this one had its limitations. As always, it would have been desirable to have a larger, more representative population. Also, this study relied on self-report, which is susceptible to various biases like impression management; it is always best to supplement these studies with observational and behavioural data. Further, most studies in this area are based on the reports of who gives rather than receives tips, and the perspective of the latter group are most important.

\section{Conflicts of Interest}

The author declares no conflicts of interest regarding the publication of this paper.

\section{References}

Aydin, A. E., \& Acun, Y. (2019). An Investigation of Tipping Behavior as a Major Component in Service Economy: The Case of Taxi Tipping. Journal of Behavioral and EXperimental Economics, 78, 114-120. https://doi.org/10.1016/j.socec.2018.12.011

Azar, O. (2005). Who Do We Tip and Why? Applied Economics, 37, 1871-1879. https://doi.org/10.1080/00036840500119018

Azar, O. (2020). The Economics of Tipping. Journal of Economic Perspectives, 34, 215-236. https://doi.org/10.1257/jep.34.2.215

Furnham, A. (1984). Many Sides of the Coin: The Psychology of Money Usage. Personality and Individual Differences, 5, 501-509. https://doi.org/10.1016/0191-8869(84)90025-4

Furnham, A. (1996). Attitudinal Correlates and Demographic Predictors of Monetary Beliefs and Behaviours. Journal of Organizational Behaviour, 17, 375-388. https://doi.org/10.1002/(SICI)1099-1379(199607)17:4<375::AID-JOB767>3.0.CO;2-8

Furnham, A. (2014). The New Psychology of Money. London: Routledge. https://doi.org/10.4324/9780203506011

Furnham, A., \& Grover, S. (2020). A New Money Behaviour Quiz. Journal of Individual Differences, 41, 17-29. https://doi.org/10.1027/1614-0001/a000299

Furnham, A., \& Grover, S. (2021). Money Psychology: Beliefs and Behaviours about Investing, Saving and Spending. In J. Grable, \& S. Chatterjee (Eds.), Handbook of Personal Finance. London: De Gruyter.

Furnham, A., \& Horne, G. (2021). A Measure of Money Madness. Paper under Review.

Furnham, A., \& Murphy, T.-A. (2019). Money Types, Money Beliefs and Financial Worries: An Australian Study. Australian Journal of Psychology, 71, 193-199.

https://doi.org/10.1111/ajpy.12219

Furnham, A., von Stumm, S., \& Fenton-O’Creevy, M. (2014a). Sex Differences in Money Pathology in the General Population. Social Indicators Research, 123, 701-713.

https://doi.org/10.1007/s11205-014-0756-x

Furnham, A., von Stumm, S., \& Milner, R. (2014b). Moneygrams: Recalled Childhood Memories about Money and Adult Money Pathology. Journal of Financial Therapy, 5, 40-54. https://doi.org/10.4148/1944-9771.1059 
Furnham, A., Wilson, E., \& Telford, K. (2012). The Meaning of Money: The Validation of a Short Money-Types Measure. Personality and Individual Differences, 52, 707-711. https://doi.org/10.1016/j.paid.2011.12.020

Gössling, S., Fernandez, S., Martin-Rios, C., Pasamar Reyes, S., Fointiat, V., Isaac, R., \& Lunde, M. (2020). Restaurant Tipping in Europe: A Comparative Assessment. Current Issues in Tourism, 24, 811-823. https://doi.org/10.1080/13683500.2020.1749244

Guéguen, N. (2002). The Effects of a Joke on Tipping When It Is Delivered at the Same Time as the Bill. Journal of Applied Social Psychology, 32, 1955-1963. https://doi.org/10.1111/j.1559-1816.2002.tb00266.x

Harris, M. (1995). Waiters, Customers and Service: Some Tips about Tipping. Journal of Applied Social Psychology, 25, 725-744. https://doi.org/10.1111/j.1559-1816.1995.tb01771.x

Karabas, I., \& Joireman, J. (2020). The Role of Blocked Gratitude in Non-Voluntary Tipping. Journal of Services Marketing, 34, 983-997. https://doi.org/10.1108/JSM-03-2020-0082

Karabas, I., Orlowski, M., \& Lefebvre, S. (2020). What Am I Tipping You for? Customer Response to Tipping at Limited Service Restaurants. International Journal of Contemporary Hospitality Management, 32, 2007-2026. https://doi.org/10.1108/IJCHM-12-2019-0981

Lynn, M. (2008). Personality Effects on Tipping Attitudes, Self-Reported Behaviours and Customs: A Multi-Level Inquiry. Personality and Individual Differences, 44, 989-999. https://doi.org/10.1016/j.paid.2007.10.025

Lynn, M. (2015a). Service Gratuities and Tipping: A Motivational Framework. Journal of Economic Psychology, 46, 74-88. https://doi.org/10.1016/j.joep.2014.12.002

Lynn, M. (2015b). Explanations of Service Gratuities and Tipping: Evidence from Individual Differences in Tipping Motivations and Tendencies. Journal of Behavioural and Experimental Economics, 55, 65-71. https://doi.org/10.1016/j.socec.2015.01.002

Lynn, M. (2018). How Motivations for Tipping Vary with Occupational Differences in Descriptive Tipping Norms. Journal of Behavioral and Experimental Economics, 77, 1-10. https://doi.org/10.1016/j.socec.2018.09.003

Lynn, M. (2021). Effects of the Big Five Personality Traits on Tipping Attitudes, Motives, and Behaviors. International Journal of Hospitality Management, 92, Article ID: 102722. https://doi.org/10.1016/j.ijhm.2020.102722

Lynn, M., \& Grassman, A. (1990). Restaurant Tipping: An Examination of Three "Rational" Explanations. Journal of Economic Psychology, 11, 169-181. https://doi.org/10.1016/0167-4870(90)90002-Q

Lynn, M., \& Latane, B. (1984). The Psychology of Restaurant Tipping. Journal of Applied Social Psychology, 14, 551-563. https://doi.org/10.1111/j.1559-1816.1984.tb02259.x

Lynn, M., Jabbour, P., \& Kim, W. G. (2012). Who Uses Tips as a Reward for Service and When? Journal of Economic Psychology, 33, 90-103. https://doi.org/10.1016/j.joep.2011.09.009

Rind, B., \& Bordia, P. (1995). Effect of Server's “Thank You” and Personalization on Restaurant Tipping. Journal of Applied Social Psychology, 25, 745-751. https://doi.org/10.1111/j.1559-1816.1995.tb01772.x

Saunders, S., \& Lynn, M. (2010). Why Tip? An Empirical Test of Motivations for Tipping Car Guards. Journal of Economic Psychology, 31, 106-113.

https://doi.org/10.1016/j.joep.2009.11.007

Shamir, B. (1983). A Note on Tipping and Employee Perceptions and Attitudes. Journal of Occupational Psychology, 56, 255-259. 
https://doi.org/10.1111/j.2044-8325.1983.tb00132.x

Shamir, B. (1984). Between Gratitude and Gratuity: An Analysis of Tipping. Annals of Tourism Research, 11, 59-78. https://doi.org/10.1016/0160-7383(84)90096-3

Strohmetz, D., Rind, B., Fisher, R., \& Lynn, M. (2002). Sweetening the Till: The Use of Candy to Increase Restaurant Tipping. Journal of Applied Social Psychology, 32, 300-309. https://doi.org/10.1111/j.1559-1816.2002.tb00216.x

Whaley, J. E., Douglas, A. C., \& O'Neill, M. A. (2014). What's in a Tip? The Creation and Refinement of a Restaurant Tipping Motivations Scale: A Consumer Perspective. International Journal of Hospitality Management, 37, 121-130.

https://doi.org/10.1016/j.ijhm.2013.11.005

Whaley, J. E., Kim, S. H., \& Kim, Y. K. (2019a). Drivers and Impact of Restaurant Tipping Behavior. Journal of Foodservice Business Research, 22, 117-131.

https://doi.org/10.1080/15378020.2019.1570773

Whaley, J. E., Lee, J., \& Kim, Y.-K. (2019b). Do Tipping Motivations Lead to Server Loyalty in a Restaurant? International Hospitality Review, 33, 91-105.

https://doi.org/10.1108/IHR-01-2019-0001 